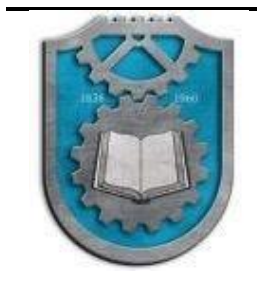

MOBILITY \& VEHICLE MECHANICS

DOI: $10.24874 / \mathrm{mvm} .2021 .47 .02 .02$

UDC: 62-833.6

\title{
ELECTRIC AND HYBRID VEHICLES: ARE WE READY FOR THE NEW MOBILITY ERA?
}

Giovanni Belingardi ${ }^{1}$, Nicola Amati ${ }^{2}$, Angelo Bonfitto ${ }^{3}$

Received in July $2020 \quad$ Revised in August $2020 \quad$ Accepted in September 2020

RESEARCH ARTICLE

ABSTRACT: Hybrid (HEV) and pure electric (EV) vehicles are nowadays considered as the new frontier for the mobility. The claim is to solve a number of problems that are affecting the person and goods mobility, from the environmental point of view but also from the safety and the traffic congestion point of views. However, some concerns, in particular about the energy sources and availability are open questions. Hybrid architectures are seen as the transition toward the purely electric solutions. But probably a wide revolution of the mobility system has to take place, with new paradigm for different mobility types. For example, urban mobility is quite different and poses different targets with respect to the long-distance mobility. Goods delivery inside the town are suitable for different solutions with respect to highway trucks transportation. The paper, after a brief overview of the proposed architectural solutions for HEV, proposes a discussion of the advantages that can be obtained by using different paradigms. Then, some open questions related to hybrid and purely electric configurations are addressed. One of the key points is the availability of battery packs with enough energy capacity, affordable costs and at reasonable prices in relation with the vehicle missions. Therefore, present research activities are devoted to the development of optimal efficiency solutions both at subsystem and complete vehicle level. In detail, we will discuss some issues related to Battery Pack systems and Battery Management System (BMS) that have not yet reached an adequate level of robustness and reliability and need further investigations.

(C) 2021 Published by University of Kragujevac, Faculty of Engineering

\footnotetext{
${ }^{1}$ Giovanni Belingardi,Politecnico di Torino - Politecnico di Torino - DIMEAS Dept. of Mechanical and Aerospace Engineering, Corso Duca degli Abruzzi, 24, Torino;CARS - Center for Automotive Research and Sustainable Mobility, Corso Duca degli Abruzzi, 24, Torino, giovanni.belingardi@polito.it (*Corresponding author)

${ }^{2}$ Nicola Amati, Politecnico di Torino - Politecnico di Torino - DIMEAS Dept. of Mechanical and Aerospace Engineering, Corso Duca degli Abruzzi, 24, Torino;CARS - Center for Automotive Research and Sustainable Mobility, Corso Duca degli Abruzzi, 24, Torino

${ }^{3}$ Angelo Bonfitto, Politecnico di Torino - Politecnico di Torino - DIMEAS Dept. of Mechanical and Aerospace Engineering, Corso Duca degli Abruzzi, 24, Torino; CARS - Center for Automotive Research and Sustainable Mobility, Corso Duca degli Abruzzi, 24, Torino
} 
The accurate evaluation of the state of charge $(\mathrm{SoC})$ and of the state of health $(\mathrm{SoH})$ becomes straightforward to properly exploit and maximize the performance of the battery pack. In addition, mechanical and thermal design issues, that include lightweight, battery pack cooling, and safety in case of impact, are additional primary points that ask for adequate viable sustainable design solutions.

KEY WORDS: HEV, PHEV, energy efficiency, battery systems, mobility paradigms

\section{ELEKTRIČNA I HIBRIDNA VOZILA: DA LI SMO SPREMNI ZA NOVU ERU MOBILNOSTI?}

REZIME:Hibridna (HEV) i čisto električna (EV) vozila danas se smatraju novom granicom mobilnosti.Tvrdnja je da se reše brojni problemi koji utiču na mobilnost ljudi i robe, sa ekološke tačke gledišta, ali i sa stanovišta bezbednosti i zagušenja saobraćaja. Međutim, neka pitanja, posebno u vezi sa izvorima energije i dostupnošću, su otvorena pitanja. Hibridne arhitekture se vide kao prelazak ka čisto električnim rešenjima. Ali verovatno se mora dogoditi široka revolucija sistema mobilnosti, sa novom paradigmom za različite vrste mobilnosti. Na primer, gradska mobilnost je prilično različita i postavlja različite ciljeve u odnosu na mobilnost na velike udaljenosti. Dostava robe unutar grada pogodna je za različita rešenja u pogledu prevoza kamionima na autoputu. Rad, nakon kratkog pregleda predloženih arhitektonskih rešenja za HEV, predlaže raspravu o prednostima koje se mogu postići korišćenjem različitih paradigmi. Zatim se rešavaju neka otvorena pitanja vezana za hibridne i čisto električne konfiguracije. Jedna od ključnih tačaka je dostupnost baterija sa dovoljnim kapacitetom energije, pristupačni troškovi i po razumnim cenama u odnosu na misije vozila. Stoga su sadašnje istraživačke aktivnosti posvećene razvoju optimalnih rešenja efikasnosti kako na nivou podsistema tako i na nivou kompletnog vozila. Detaljno ćemo razgovarati o nekim pitanjima vezanim za sisteme baterijskih paketa i sistema za upravljanje baterijama (BMS) koji još nisu dostigli odgovarajući nivo robusnosti i pouzdanosti i potrebna su dalja istraživanja. Precizna procena stanja napunjenosti (SoC) i zdravstvenog stanja $(\mathrm{SoH})$ postaje jednostavna za pravilno iskorišćavanje i maksimiziranje performansi baterije. Osim toga, mehanička i termička pitanja dizajna, koja uključuju laganost, hlađenje baterije i sigurnost u slučaju udara, dodatne su primarne tačke koje traže adekvatna održiva rešenja za dizajn.

KLJUČNE REČI: HEV, PHEV, energetska efikasnost, sistemi baterija, mobilnost paradigme 


\title{
ELECTRIC AND HYBRID VEHICLES: ARE WE READY FOR THE NEW MOBILITY ERA?
}

\author{
Giovanni Belingardi, Nicola Amati, Angelo Bonfitto
}

\section{INTRODUCTION}

Government regulations on fuel economy and emissions introduced stringent requirements in automotive sector. Carmakers are called to reduce drastically the amount of pollutants with the goal of a more sustainable mobility, as illustrated in Figure 1. In this scenario, the strong incentive to produce alternative powertrain technologies has created a mix of different configurations and architectures for the vehicle traction. Side by side with the refinement of standard ICE-based vehicles, pure electric (EV), hybrid electric (HEV) and fuel cell hybrid electric (FCHV) powertrain gained an increasing attention in the last decade. As a matter of fact, FCHVs are still in a development phase, whilst EVs and HEVs are already common and affordable solutions that have established as reliable alternative to ICEs and gained a relevant momentum in the automotive market [1-3].

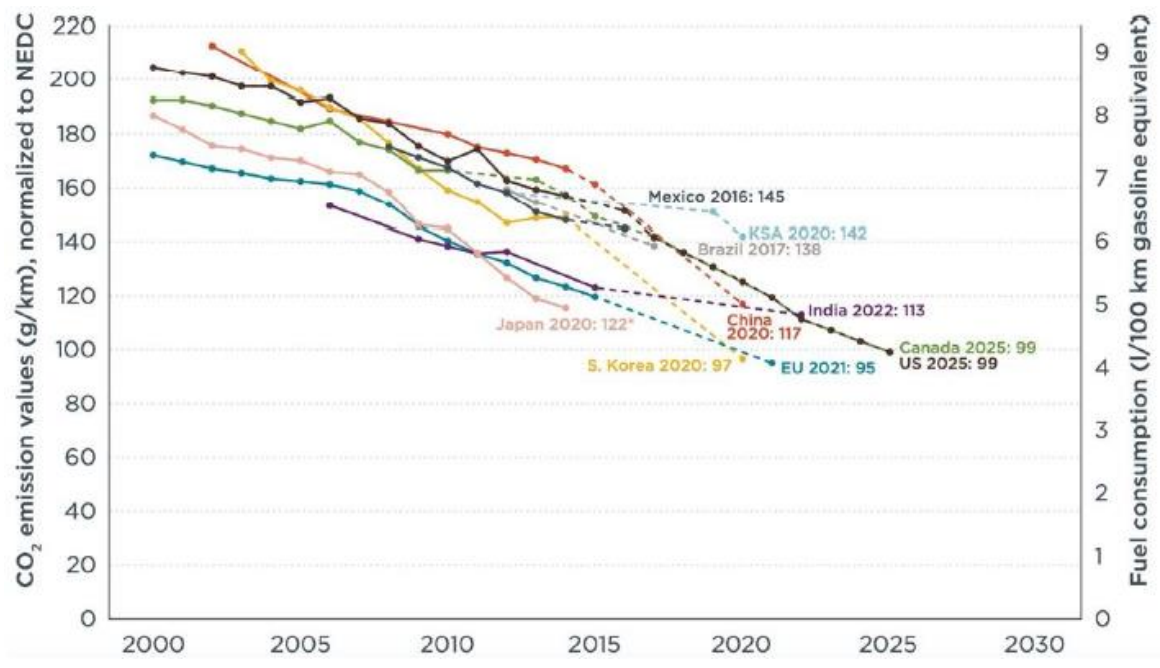

Figure 1 Fleet CO2 emissions by country normalized to NEDC homologation driving cycle for passenger cars. Solid line: Hystorical values. Dashed lines: target values

The technology of EVs can be considered mature and the main room for improvement have to be ascribed to the research of battery technology aimed to improve the autonomy range, that is currently settled around $400 \mathrm{~km}$. In the same time, HEVs can be considered as a bridge between the ICEs and the pure electric traction. This technology is variegate, with many possible powertrain architectures and margins of development and improvement in several aspects. This paper provides an overview of the current status of the technology of EVs and HEVs and addresses the main aspects on which the research and the industrial developments are focusing their attention. Specifically, an overview of the possible hybrid powertrain architectures is provided with the analysis of the functions of each layout and a description of the sizing of the subcomponents for the different layouts. Afterwards, a discussion on the current status and on the development perspectives of the energy 
management controllers and battery pack is conducted. In particular, an analysis of the chemistry, cost, monitoring and sizing allows evaluating which sides of the battery technology still present margin of improvement.

However, the main objective of the paper is to highlight that the properties and advantages of powertrain electrification and hybridization may be fully exploited only when also the other components of the vehicle are designed to have the maximum efficiency. To this end, the electrification of vehicles subsystems can lead to relevant advantages in terms of fuel consumption and emission reduction. The attention in the present work is focused on three aspects: chassis electrification, specifically regeneration from shock absorbers and vehicle height adjustment, recuperation from gas exhaust, and reduction of the organic ICE losses by means of electrified accessories (i.e. e-water pump). A general trend on the development of these aspects is proposed and some specific solutions are presented along the discussion.

\section{HYBRID ELECTRIC VEHICLE ARCHITECTURES}

A first systematization of the hybrid architectures is based on the analysis of the energy flow from the sources (motor generators and ICE) to the wheels. According to this classification, the three layouts illustrated in Figure 2 are identified: parallel, series, and power-split. In parallel architectures, the power combination of the engine and electric machine/s is obtained through a mechanical connection with a gear set, a chain, or a belt. The two torque contributions are summed and transmitted to the wheels. Series architectures are designed to have electrical connection between the power generation and the wheels. The engine mechanical energy is converted in electrical and summed to the contribution coming from the batteries. The series-parallel combination allows exploiting the two layouts through the engagement and disengagement of one or two clutches to use one layout rather than the other according to the operating driving conditions. Power-split architecture combines the parallel and series layout with the adoption of a planetary gear set, the elimination of the gearbox and two electric machines [3-5].

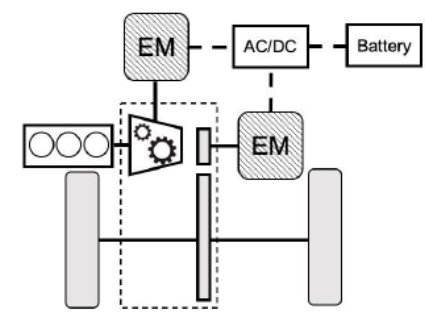

a)

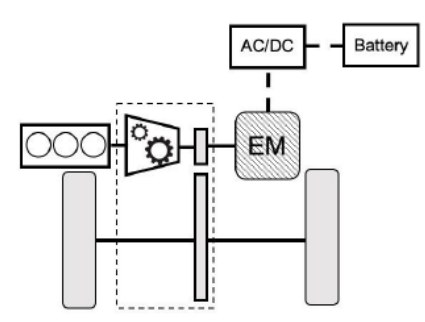

b)

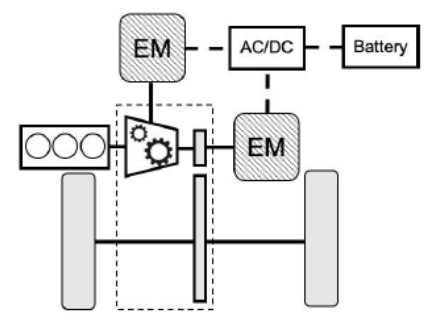

c)

Figure 2 Series (a), parallel (b), and power-split (c) architectures

A further classification method is based on the degree of hybridization, i.e. on the size of the electric powertrain, and includes the following categories : 1) Micro hybrids. The nominal voltage of the electric machine is not higher than $12 \mathrm{~V}$ and allows for the possibility of Start\&Stop implementation. 2) Mild hybrids. The nominal voltage of the motor generator in this configuration is typically $48 \mathrm{~V}$ but solutions with $24 \mathrm{~V}$ can be found on the market, as the solution introduced by Mazda in 2020. This layout offers regenerative braking and engine assist functions, 3) Full hybrids, in which previous functions are merged together with the additional capability of battery-only operation, and 4) Plug - in hybrids, for which the main peculiarity is the possibility to connect the electric battery to the electrical grid. The last 
classification approach is based on the position of the secondary energy converter and is illustrated in Figure 3.
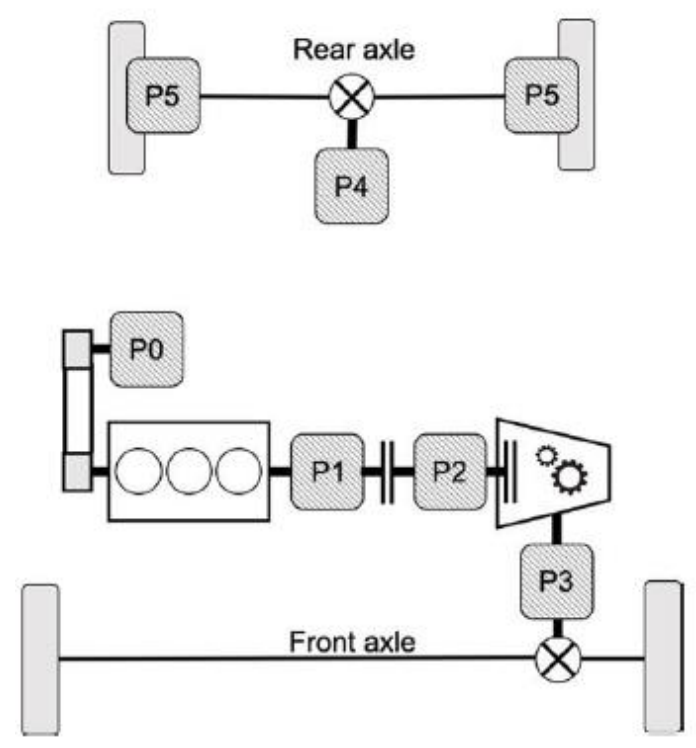

Figure 3 Hybrid Electric Vehicle architectures based on the position of the secondary energy converter

The categories of Hybrid vehicles based on this classification are: P0) The standard alternator mounted on the frontend accessory drive (FEAD) is substituted by a more powerful and efficient electric machine. Regenerative braking is allowed but its efficiency is low due to the number of dissipative components (differential, gearbox, ICE, belt transmission) between the wheels and the electric generator. The ICE forces the former to be designed for high speeds $(15-18 \mathrm{krpm})$ while the limited space for the installation limits the torque and power. P1) The electric machine is located directly on the engine crankshaft (transmission side). A more efficient regenerative braking can be achieved in this case due to the absence of the FEAD. The motor can assist engine and, when integrated inside the flywheel, improve attenuation of the torque oscillations. However, due to its position it has to comply to stringent requirements about the axial size due to integration issues in the powertrain. P2) In this configuration, the electric motor is mounted downstream the mechanical clutch and the complete uncoupling between vehicle and ICE can be performed. Pure electric mode is allowed without dragging the engine inertia and its organic losses. Axial size requirements still drive the design. This layout has a strong impact on the powertrain design, since it forces the complete re-design of the transmission. P3) Moving downstream the overall driveline, the electric motor can be placed at the input or output of the secondary transmission shaft. It owns the same characteristics of P2 configuration, but regenerative braking is in this case maximized because of the presence of the differential only between front wheels and electric motor. High values of torque are requested to the electric machine since no stage of torque amplification, such as the gearbox, is present between it and the wheels. P4) Within this layout the attention is moved on the opposite axle with respectto the one in which the ICE is positioned. The electric motor is connected to the wheels by means of a differential (of whatever kind) and although a re-thinking of the electric axle should take 
place. This configuration offers the possibility of maximizing the recovery of the energy together with giving full potentials to the electric driving. P5) The electric machines are installed directly on the wheels. Limitations on the torque are present due to the small axial size of the machine [6]. This solution is rarely adopted by carmakers. Table 1 summarizes the main layout characteristics and function properties of hybrid electric vehicles categorized according to the aforementioned approaches.

Table 1Properties and characteristics of hybrid architectures categorized according to the size of the electric powertrain

\begin{tabular}{|c|c|c|c|c|c|}
\hline & & $\begin{array}{l}\text { Micro } \\
\text { hybrid }\end{array}$ & $\begin{array}{c}\text { Mild } \\
\text { hybrid }\end{array}$ & Full hybrid & $\begin{array}{l}\text { Plug-in } \\
\text { hybrid }\end{array}$ \\
\hline \multirow{5}{*}{ 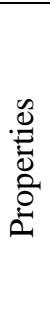 } & Battery voltage [V] & 12 & $24-48$ & $>200$ & $>200$ \\
\hline & $\begin{array}{l}\text { Electric machine power } \\
{[\mathrm{kW}]}\end{array}$ & $2-5$ & $10-20$ & $20-50$ & $30-120$ \\
\hline & Battery chemistry & Lead-acid & $\begin{array}{l}\text { Li-ion, } \\
\text { NiMH }\end{array}$ & Li-ion & Li-ion \\
\hline & Battery capacity [kWh] & $<1$ & $<1.5$ & $<10 \mathrm{kWh}$ & $<40 \mathrm{kWh}$ \\
\hline & $\begin{array}{c}\text { Estimated } \mathrm{CO} 2 \text { emission } \\
\text { reduction }\end{array}$ & $<5 \%$ & $<15 \%$ & $<20 \%$ & $<40 \%$ \\
\hline \multirow{8}{*}{ 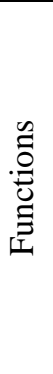 } & Start \& Stop & $\mathrm{Y}$ & $\mathrm{Y}$ & $\mathrm{Y}$ & $\mathrm{Y}$ \\
\hline & Boosting & $\mathrm{Y}$ & $\mathrm{Y}$ & $\mathrm{Y}$ & $\mathrm{Y}$ \\
\hline & $\begin{array}{l}\text { Regeneration from } \\
\text { braking (engine off) }\end{array}$ & $\mathrm{N}$ & $\begin{array}{l}\text { Y (no P0, } \\
\text { P1) }\end{array}$ & Y & Y \\
\hline & Pure electric mode & $\mathrm{N}$ & $\mathrm{N}$ & $\mathrm{Y}$ & $\mathrm{Y}$ \\
\hline & Regeneration from ICE & $\mathrm{Y}$ & $\mathrm{Y}$ & $\mathrm{Y}$ & $\mathrm{Y}$ \\
\hline & Cold Engine cranking & $\mathrm{N}$ & $\mathrm{Y}($ no P0) & $\mathrm{Y}$ & $\mathrm{Y}$ \\
\hline & Sailing/Coasting & $\mathrm{N}$ & $\mathrm{Y}($ no P0) & $\mathrm{Y}$ & $\mathrm{Y}$ \\
\hline & Creeping & $\mathrm{N}$ & $\mathrm{Y}($ no P0) & $\mathrm{Y}$ & $\mathrm{Y}$ \\
\hline
\end{tabular}

In some of the described architectures, the impact on the overall vehicle structure is marginal, i.e. in the case of micro-hybrid and mild P0, whilst in some others, the powertrain should be consistently modified. Therefore, in order to reduce the time to market and gain short terms benefits, manufacturers tend to avoid the complete powertrain and car body re-design in order to find a place for electric battery, power electronics and electric motors. The statistics of market penetration of hybrid and electric vehicles in the market are illustrated in Figure 4. 


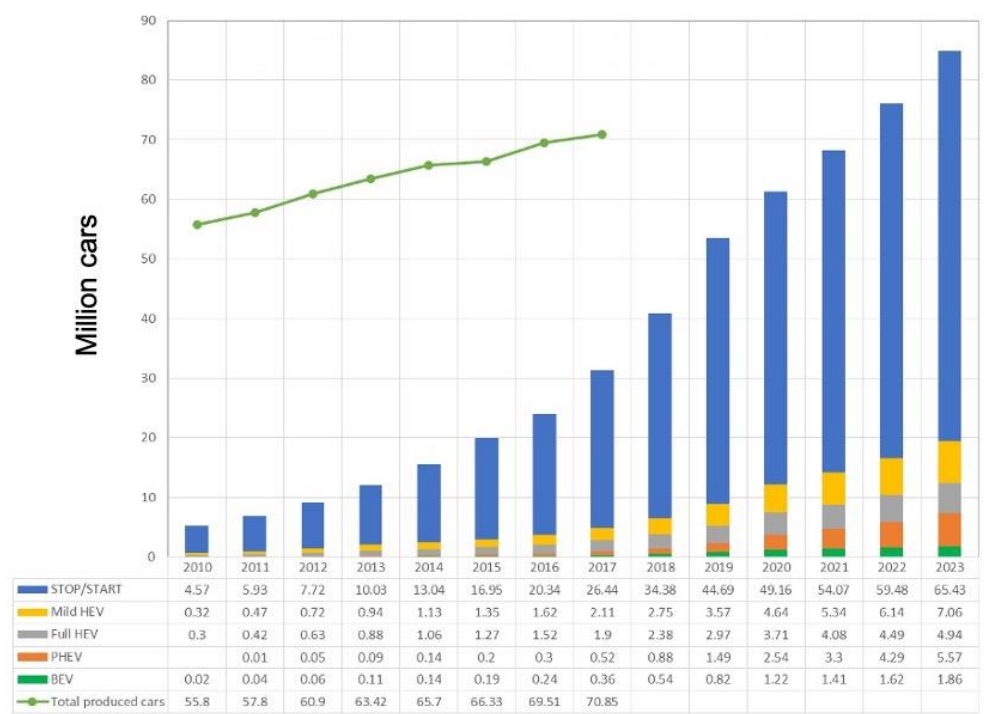

Figure 4 Statistics of penetration of hybrid electric vehicles in the market

\section{BATTERY AND CONTROL STRATEGY ANALYSIS}

The electrification and hybridization of a vehicle include a multidisciplinary and transversal integration of many aspects, ranging from the mechanical to the electrical, passing through control logic and electrochemical behaviour of the batteries. In this paper, the attention is focused on some aspects that are of relevant importance in the design of the vehicle: the battery pack, control strategies and electrification of the accessories.

\subsection{Battery pack}

Batteries have a huge impact in the design of a hybrid or pure electric vehicle. The technology and management of this pivotal component witnessed a steady improvement in the last decade, driven by the always growing figures of electrical powertrains in automotive industry. Extensive studies regarding the battery are present in the literature. Here, an analysis is conducted considering the following aspects: chemistry, sizing, specific energy and power, performance, lifespan, charging time, monitoring, safety, and cost. 


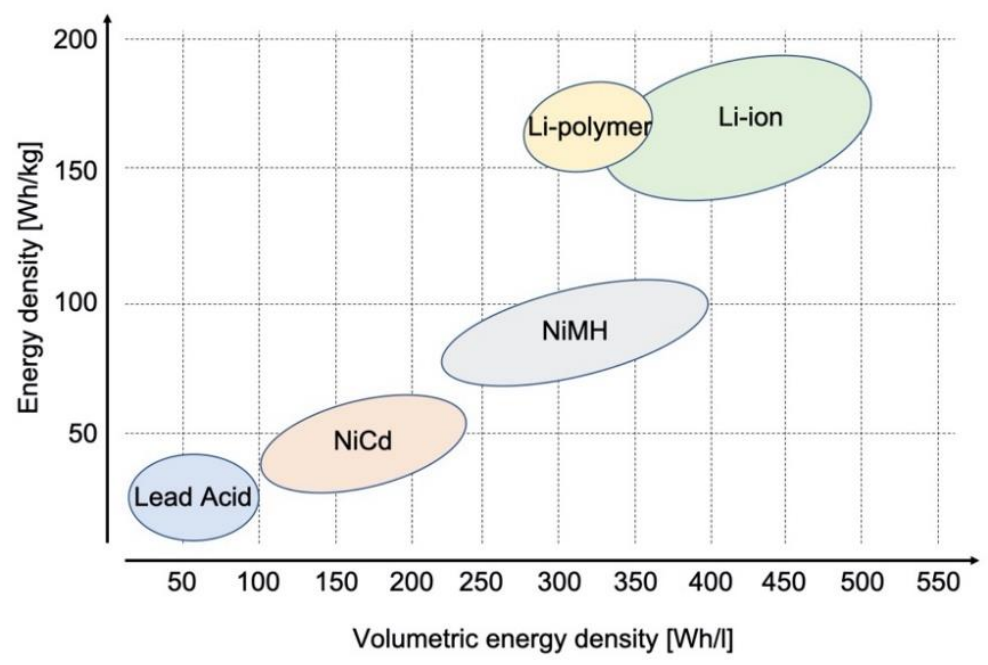

Figure 5 Energy density of the main battery technologies adopted in automotive industry

Nowadays, almost all pure and hybrid electric vehicles are equipped with Lithium-ion (Liion) batteries. However, some carmakers (e.g. Toyota) are still using Nichel Metal-Hydrade (NiMH) for some of their vehicles. As a matter of fact, NiMH features less energy density with respect to Lithium-ion, as illustrated in Figure 5, it has $25 \%$ more weight and occupation, and cannot perform long charge cycles, which limits the adoption for plug-in vehicles. On the other hand, it does not require a Battery Management System and has higher performance in case of low temperature. The on-going research on the battery chemistry is focused on Sodium-ion and Lithium-Sulfur with a targeted energy density of $400 \mathrm{Wh} / \mathrm{kg}$. Lithium-ion batteries are based on a set of different chemistries. The most common chemistries of Li-ion in automotive industry are: Lithium-Nichel-CobaltAluminum (NCA), Lithium-Nichel-Manganese-Cobalt, Lithium-Manganese-Spinel (LMO), Lithium-Titanate (LTO), and Lithium-Iron-Phosphate (LFP). Lithium-Cobalt oxide (LCO), that is very common in consumer devices, is not used in automotive for safety issues. Safety is the most important criterion for the selection of the chemistry. The most dangerous threat of a battery is the occurring of the thermal runaway, that consists of unexpected chemical reactions which obstruct the heat release and can result in a fire. The causes of this misbehavior overcharging, high discharging rates, or possible short circuits. Chemistries that are most exposed to this phenomenon are NCA, NMC, and LMO, which at the same time offer higher energy density. They must be used in combination with a robust battery box, efficient cooling system, and reliable battery pack monitoring to avoid overcharging and deep discharging [7][8]. A precise state of charge (SOC) and State of Health (SOH) monitoring is also very useful to avoid psychological collateral effects, such as the range anxiety of the driver, extend the lifespan of the battery and improve hybridization performance [9][10]. Current common solutions for the SOC and SOH monitoring are based on the adoption of Look-Up Tables (LUTs) filled with preliminary experimental characterization conducted in laboratory environment, that are extremely time-consuming and require high computational cost and extremely large memory for the maps. Alternative approaches are the model-based techniques, such as Extended Kalman Filter (EKF) or Smooth Variable Structure Filter (SVSF). These techniques might suffer inaccuracies due to the difficulty in reproducing all the operating conditions on the embedded reference model. An approach that is gaining growing attention is the adoption of Artificial Intelligence, such 
as neural networks. This technique is model-less, do not require high computational cost and has good accuracy performance, provided that the training dataset is sufficiently complete and well reproducing a wide set of operating conditions of the batteries in different charging/discharging cycles and at different levels of degradation of the battery. The possibility of enlarging the lifespan of a battery through the adoption of proper monitoring techniques is indeed very important for the carmakers. In automotive industry, a battery is considered exhausted when $20 \%$ of capacity or power fading is reached. As a matter of fact, some carmakers select the battery size planning eight to ten years of life for the batteries. Others prefer to downsize the battery capacity planning warranty programs. The sizing of the battery is strongly depending on the architecture and on the planned use of the vehicle. Currently, the attention of the carmakers is focused on enlarging the specific energy (capacity per unit of weight) rather than specific power (power per unit of weight). This is motivated by the necessity of improving the autonomy range of the vehicle more than the power that is already equal or even higher than the ICEs'. The technical considerations have to be conducted in conjunction with the cost analysis of a battery pack. Current cost of the batteries is settled at around $250 \$ / \mathrm{kWh}$. This number was four to six times higher only ten years ago. The cost is obviously depending on the volumes and on the price of raw materials, assembly and equipment. Further descending is expected in the next future, even with a less steep trend. The large scale, the research of new chemistries and the optimization of the production processes will help this progress along with the reduction of the recharging time and the increasing of the charging stations, which will improve the customer perception of electric vehicles.

\subsection{Energy flow management strategies}

As above mentioned, a correct estimation of the available energy in the batteries (SOC) is crucial for the effectiveness of the energy flow supervisor of the hybrid electric vehicle. This controller decides which is the amount of power that the energy sources of the vehicle have to provide at each instant. Its role is of utmost importance since it allows optimizing performance, minimizing fuel consumption and emissions and keeping the battery working in safe conditions. Moreover, a correct flow management gives the possibility of exploiting the maximum potential of the hybridization and of the vehicle functions. Once defined the architecture and the size of the subsystems of a hybrid vehicle, the controller is on charge of providing the correct logic to make the vehicle compliant with the regulations [11][12][13][14]. Specifically, when it comes to fulfill the requirements imposed by the regulations, such as the Worldwide Harmonized Light-vehicle Test Procedure (WLTP) and on the road with the Real Driving Emissions (RDE), the controller must guarantee the correct charge sustaining and charge depleting behavior of micro, mild, full and plug-in hybrid vehicles. The energy management strategies for a HEV are categorized in two classes: model-based and rule-based techniques. Model-based solutions can be furtherly divided in numerical (dynamic programming and genetic algorithms) and analytical (Pontryagin's minimum principle and Equivalent Consumption Minimization Strategy (ECMS)). These techniques aim to define the optimal solution giving a known driving cycle. Due to this characteristic, these solutions are non-causal and cannot be adopted on real vehicles since the future driving cycle is never known a-priori. ECMS is the only modelbased strategy that can be used in real time since it provides a local optimization solution and does not require the a priori knowledge of the operating conditions. On the contrary, rule-based solutions, such as Fuzzy Logic and Charge and Deplete, are based on a set of conditions that are defined by the designer on the basis of his expertise and are completely causal approaches.Typically, the design of the supervisor is driven by the necessity of minimizing the $\mathrm{CO} 2$ emissions with respect to the stringent regulations, enlarging the 
battery lifespan, and reducing consequently the fuel consumption to satisfy the customer expectations. Future developments of the energy management strategies will be linked to the integration of information coming from sensors (camera, lidar, etc.) and connectivity features to improve the control performance and adapt it to the driving cycle and environment conditions.

\section{EFFICIENCY IMPROVEMENT OF VEHICLE SUBSYSTEMS}

Improvement of battery system performance and their proper utilization as well as the improvement of the hybrid system control strategies remain two relevant aspects on which carmakers are spending large efforts. The main objective is to reduce the fuel consumption and the $\mathrm{CO} 2$ emission. To maximise this task, an improvement of the efficiency at vehicle level has to be taken into account in order to avoid that the efforts on battery systems and control strategy improvements are drastically mitigated. To fill this gap, it will be shown the effectiveness of the electrification of some parts both at the powertrain and chassis level.

\subsection{Improvement of ICE efficiency}

The increment of the thermodynamic efficiency remains a permanent demand of the automotive industry. This motivates a huge effort in the research of novel fuels, improved ignition laws, new cycles. In the last decade, a relevant effort has been dedicated to the reduction of the internal combustion engine organic losses. This by the introduction of new low friction materials and lower viscosity fluids for lubrications. Additionally is has been improved the efficiency of the front accessory drives and of the valve drives (belts, bearings, tensioning devices). The last results show that margins for improvements are already possible but that they are becoming always more limited. The electrification of some components opens to the opportunity of increasing not only the efficiency of the component itself but also that of the engine. In the present section are presented the benefits coming from the electrification of the water pump, the front accessory drive tensioning device, the electrification of the $\mathrm{A} / \mathrm{C}$ compressor, the turbo compound.

\subsubsection{Electrified water pump}

Standard cooling systems exploit a direct mechanical connection between the centrifugal pump and the belt drive system. In this condition, the pump is always connected and the coolant circulates in the engine in all the operating conditions, even when cooling is not desired. Being the device not controllable, the design of the pump is referred to the worst case (low speed at high ambient temperature). Therefore, in many operating conditions the amount of cooling flow driven by the pump is much higher with respect to the needed flow. Also the engine warm-up is therefore penalized. Consequently, not only the cooling efficiency is limited but also the engine efficiency is reduced [15][16][17][18]. Two different solutions are proposed to overcome this limitation. They are illustrated in Figure 6. Solution (a), reported in the left side of the picture, is referred to the activation of the water pump with a discrete on/off logic to operate the pump only when needed. This task is accomplished by introducing an electromagnetic clutch able to uncouple the impeller from the pulley driven by the belt or by introducing a moving friction wheel that can engage or disengage the water pump pulley. A fuel saving up to 1.2\% (WLTP driving cycle) can be achieved by such a function. Solution (b) is represented in the right side of Figure 6 . In this case the pump is driven by an electric motor. The pump is thereforetotally uncoupled from the crankshaft and can be powered following the exact needs of the internal combustion engine thermal level by controlling the motor speed. A fuel saving of $3 \%$ (WLTP driving cycle) has been obtained in that case. 


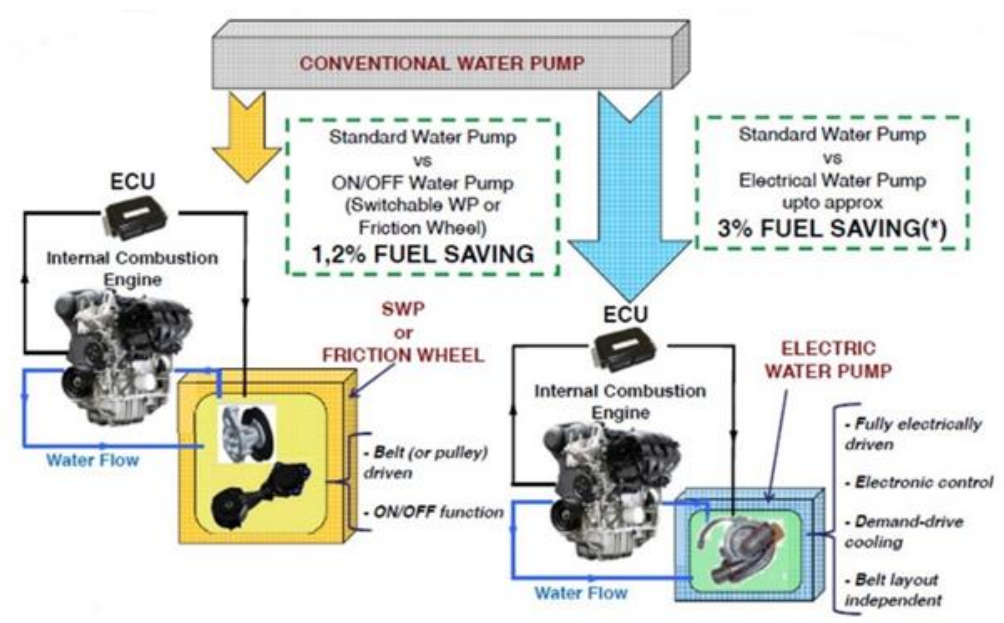

Figure 6 Solutions for more efficient operation of the cooling water pump

\subsubsection{Active tensioning device for accessory drives}

Accessory belt drives are affected by power losses linked to the dissipations in the bearings, tensioning systems, belt. The main contribution is ascribed to the belt and the belt power loss is affected by the preload which should be high enough in order to allow the correct power trainsmission in all the range of transmitted torque. In a conventional system the installation preload should cover the worst case. An additional preload should be considered in order to take into account the elongation of the belt and therefore the reduction of the preload during the belt life. It is evident that in many operating condition the belt preload is much higher with respect to the requested one. Some numerical values can help to understand the term of the problem. In a high performing belt drive for Micro Hybrid P0 system, the power loss of the belt drive at the idling speed of $800 \mathrm{rpm}$ at the belt preload of $180 \mathrm{~N}$ is equal to $380 \mathrm{~W}$ and the global transmission system efficiency is equal to $96 \%$. At the same idling speed a preload of $600 \mathrm{~N}$ leads to a power loss of $750 \mathrm{~W}$ and decrement of the efficient up to $90 \%$. An active device able to regulate the belt preload according to the actual needs can help to improve the system efficiency. In Figure 7 is reported an example of active tensioning device able to modify the belt tension from about $300 \mathrm{~N}$ up to more than $600 \mathrm{~N}$. The arm in this case is driven by a geared electric motor. The internal mechanism is conceived so that the tensioner at low tension works as a conventional automatic tensioner while to achieve high tension, the tensioner arm is controlled rigidly by the driving unit. The active tensioning system, able to reach a belt tension up to about $600 \mathrm{~N}$ is functional to the operation of the electric machine connected to the belt as a motor to fulfill tasks as engine start and e-traction in which the torque direction is opposite with respect to the generation or recuperation. Take into account that the change of direction of the torque in the e-machine inverts the tension level in the tension span and therefore the law of power transmission. 


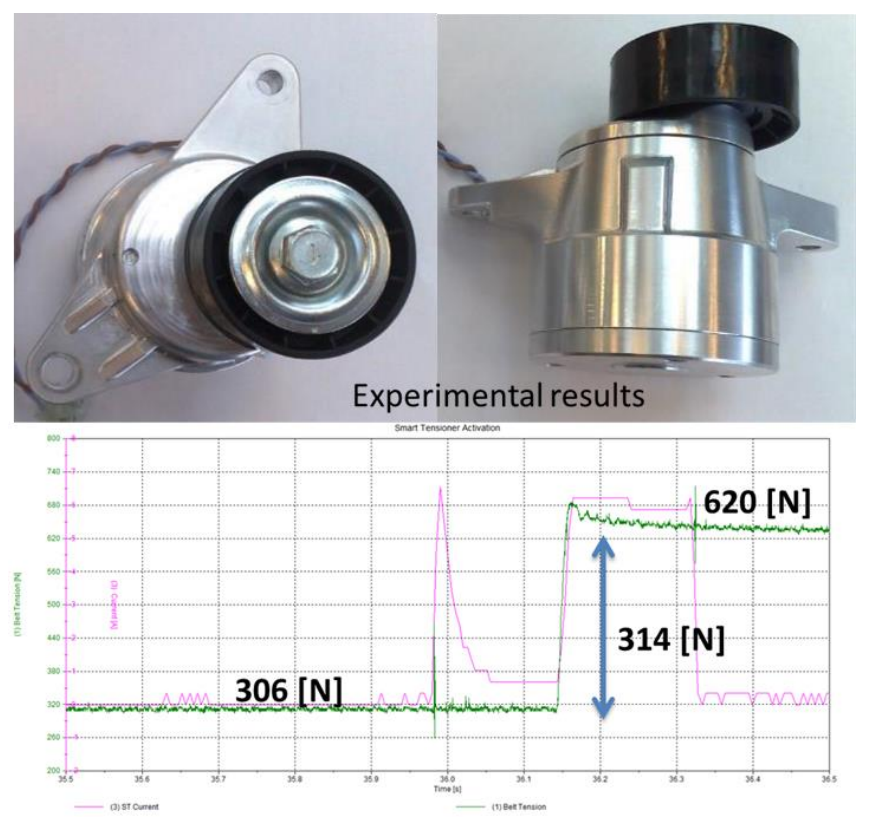

Figure 7 Example of active tensioning device and its performace

\subsubsection{Electrification of the $\mathrm{A} / \mathrm{C}$ compressor}

The A/C compressor is powered by the ICE throughout the accessory belt drive system in conventional layouts. The compressor can be switched on or off by means of an electromagnetic clutch located in between pulley connected to the belt and the compressor unit. A proper duty cycle controls the operation of the compressor. The electrification of the compressor is intended in the sense that it is powered by an e-motor. This is conceived in hybrid powertrains in which the kinetic energy recovered by the electric machine is reused to power the $\mathrm{A} / \mathrm{C}$ compressor driving the e-motor. The chain of the efficiency in this case results to be higher with respect to driving the $\mathrm{A} / \mathrm{C}$ compressor passing thought the ICE that has low efficiency. This concept is valid for all the auxiliaries or accessories that are powered by the ICE. The electrification of the A/C compressor has a benefit also in terms of comfort of the vehicle occupants because the vehicle compartment temperature and humidity can be controlled also with the ICE off. In P0 hybrid systems, an alternative to drive the $\mathrm{A} / \mathrm{C}$ compressor by an e-motor is to introduce a clutch between the crankshaft nose and the accessory belt drive system crankshaft pulley. In this case the ICE crankshaft can be decoupled by all the accessories connected to the belt. They can be powered by the BSG motor. Simulation analysis confirm a fuel saving of $2 \%$ if a WLTP driving cycle is followed.

\subsubsection{Electrification of the turbocompoud}

The management of the energy and the potential energy recuperation at the level of the exhaust gases merits a dedicated discussion. It is well known that approximately one third of the energy produced by the combustion is lost in the exhaust gases. The remaining energy is splitted in mechanical (about one third) and thermal (about another third). In engines equipped with turbocompressors part the energy lost in the exhaust gases is recuperated by 
the turbine to power the compressor that compresses the inlet air in the cylinders. Nevertheless, a large amount of power is lost as the power needed by the compressor is less with respect to the power that the turbine can theoretically recuperate in most of the working point. Figure 8 reports the turbine and compressor working points in a 2.5 liter diesel engine. The amount of energy that can potentially be recuperated is evident. The electrification of the turbocompound means that an e-machine is installed in the system to recuperate part the wasted energy. Among the several configurations that have been proposed in the literature, one of the most promising considers and e-machined installed on the mechanical connection between the turbine and the compressor impeller as shown in Figure 9. Such a configuration leads to minimize the turbolag effect being the e-machine able to supply torque to the compressor at low engine speed when the power provided by the turbine is not enough to drive the compressor. In Figure 10 are reported two examples of eturbocompounds having the e-machine installed in between the compressor and the turbine ad able to manage a power ranging from 2 to $5 \mathrm{~kW}$. A lot of effort has been dedicated to the development of the technology that is now mature for the industrialization process. Simulations carried out at power unit system level highlight that improvements are potentially possible but a proper turbo matching is requested. Figure 11 shows the increment of the global efficiency expressed as

$$
\eta_{g l}=\frac{P_{\text {mechanical }}+P_{\text {electric }}}{\dot{m}_{\text {fuel }} \cdot H_{i}}
$$

Power thrown away through the waste gate valve Turbocompressor work points

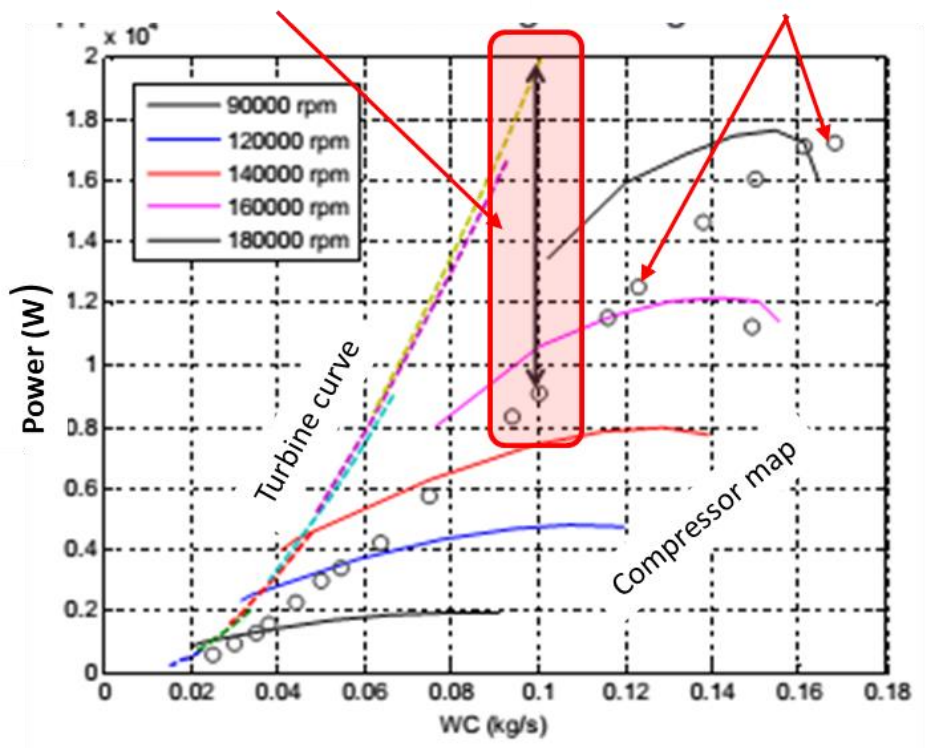

Figure 1 Compressor and turbine map 


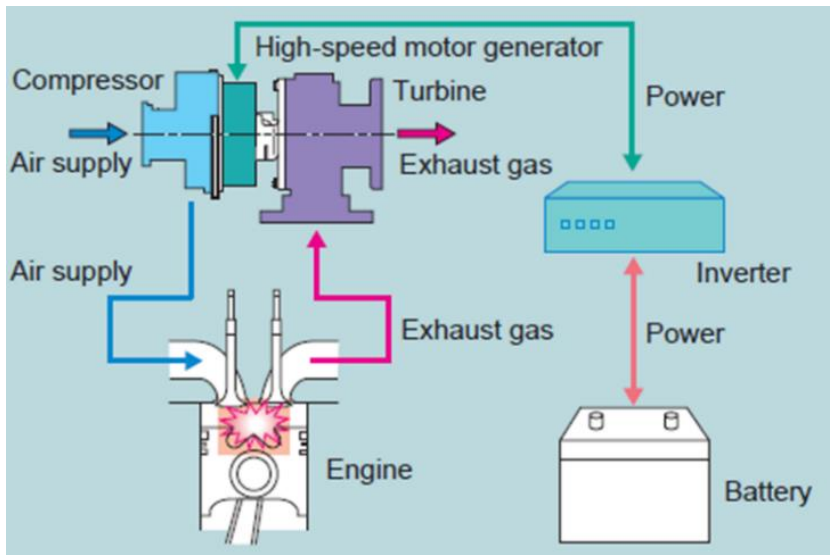

Figure 9 Scheme of e-tubocompound installed on the turbine-compressor shaft

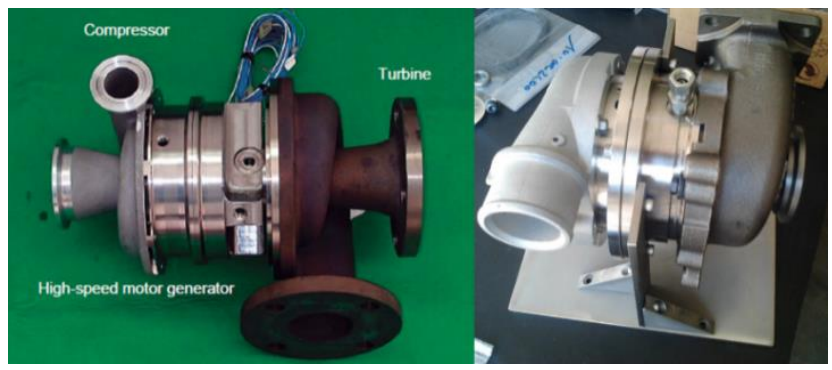

Figure 10 Examples of e-turbocompounds (e-machine installed in between the turbine and compressor)

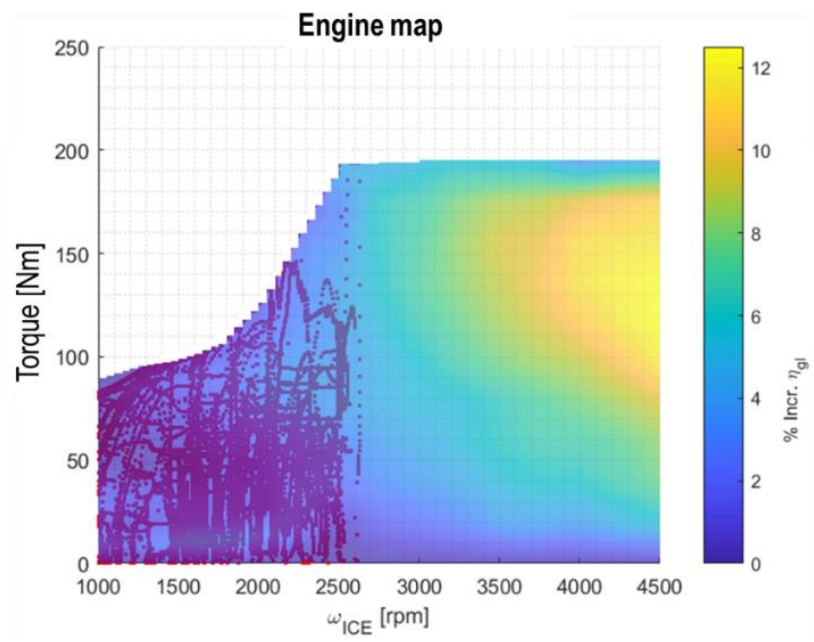

Figure 11 Engine map with possible improvments 
In the different working region of a 1.2 liters ICE equipped with a $8 \mathrm{~kW}$ e-turbocompound. It is evident that improvements up the 10-12\% of the global power unit efficiency are possible at high speed and high torque of the ICE. The dark blue points refer to the working points that are covered by the ICE during a WLTP driving cycle. The benefits in this case are marginal. The conclusion is that there are benefits with significant improvement of the global efficiency in case of a proper matching between the ICE working points and characteristics of the e-turbocompound. The performance obtained in F1 race car power units confirm the above mentioned considerations.

\subsection{Chassis electrification}

In the common belief the electrification in the modern vehicles is a process that is typically devoted to improving the efficiency of the powertrain system as described in the previous section. The objective of improving the vehicle efficiency leads to consider potential improvements also at chassis level. The adoption of electromechanicalsolutions can be considered of great importance. In this context, two applications are gaining increasing attention and are object of academic and industrial development: vibrational energy recuperation from the suspension shock absorbers and improvement of the aerodynamic efficiency by adapting the vehicle attitude according to the load and driving condition.

\subsubsection{Regenerative shock absorbers}

Vehicles equipped with regenerative shock absorbers can transfer the vibrational energy coming through the road irregularities into electricity. To realize the regeneration target, the developed device should be able to vary their damping behaviors while converting part of the dissipated power into electricity. Therefore, an electric machine together with a suitable transmission system needs to be integrated to the vehicle suspension. Several typologies of have been investigated during the last years. Here are described two solutions: regenerative shock absorber employed with electro-hydrostatic and electro-mechanical actuation principle. The former uses a hydraulic actuator directly interfaced with a motor-pump group by means of hydraulic circuit to convert the linear motion of the piston into rotation. To maximize the energy regeneration as well as to guarantee the damping features, the hydraulic, mechanical and electric subsystems must be integrated and optimized as an entire system. On the other hand, the electromechanical approach allows obtaining good performance by using an electric machine working in generation mode that has to be properly driven to optimize the energy recovering by guaranteeing the right trade-off between the handling of the vehicle and the comfort of the passengers. Figure 12 shows an example of electrohydrostatic solution developed for a segment B passenger car while Figure 13 is referred to an electromechanical configuration conceived for the same vehicle. In addition to comfort benefits related to the control of the damping to improve the vertical acceleration of the passenger compartment, benefits in terms of $2.5 \mathrm{gCO} 2 / \mathrm{km}$ ( 4 corners) have been proved experimentally in the case of an ISO class $\mathrm{C}$ ground condition $[20][21][22][23]$. 


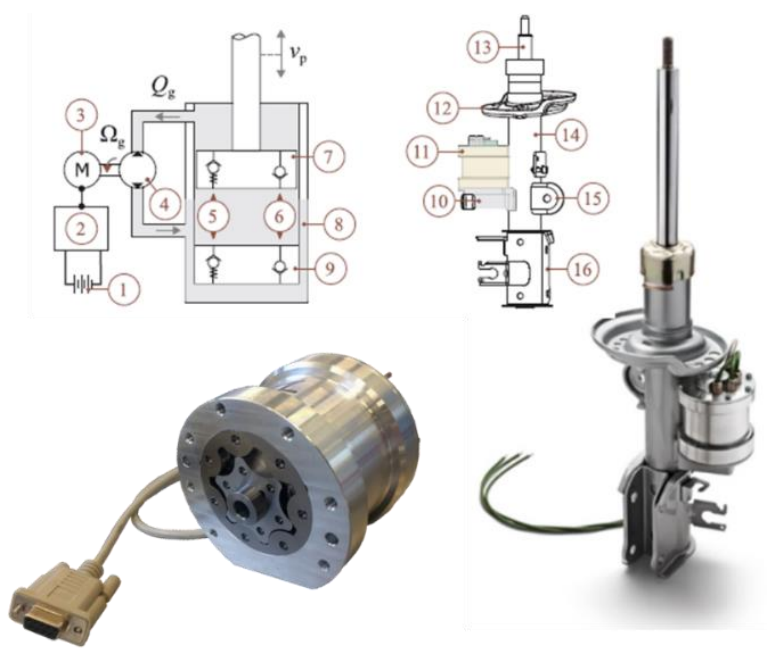

Figure 12 Electrohydrostatic technology and application
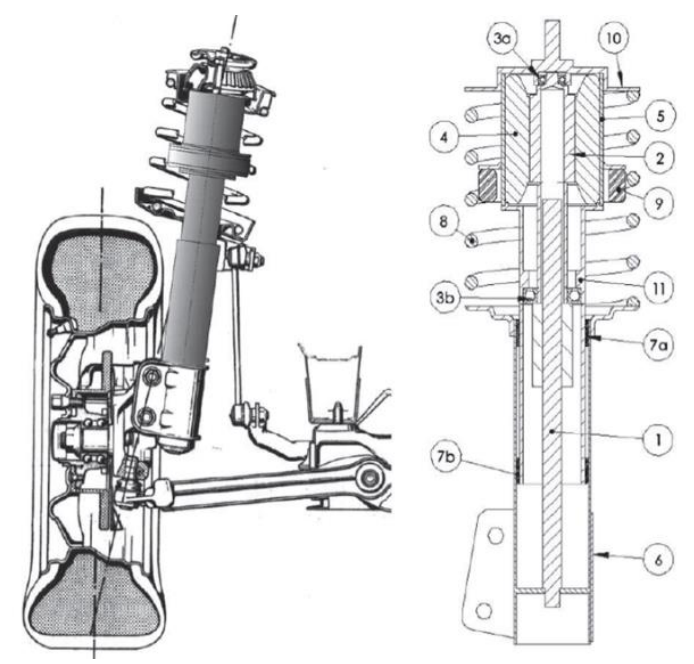

Figure 13 Example of electomechanical regenerative shock abosorvers

\subsubsection{Height adjustment}

Height adjustment systems are conceived to modify the attitude of the vehicle body in terms of static pitch angle and height from the ground according to the driving path and load condition in order to achieve a minimum aerodynamic drag coefficient in all the vehicle driving condition. The concept was implemented by Citroen in the ' 970 by using an hydropneumatic solution that recently was abandoned for cost reasons. Nevertheless, the interest for the improvements of the vehicle aerodynamics remains a current need. To this end, Figure 14 shows the effect of the aerodynamic drag coefficient on the fuel consumption with reference to a segment $\mathrm{B}$ passenger car. The reduction of $\mathrm{Cx}$ from 0.35 to 0.31 , as depicted in the figure, is achieved by reducing the height of the vehicle body from the 
ground of $50 \mathrm{~mm}$. The industrial interest is nowadays mainly devoted to the implementation of electromechanical non - reversible solutions that control the position of the lower spring holder with respect to the vehicle body. In Figure 15 is reported a schematic representation and a vehicle implementation.

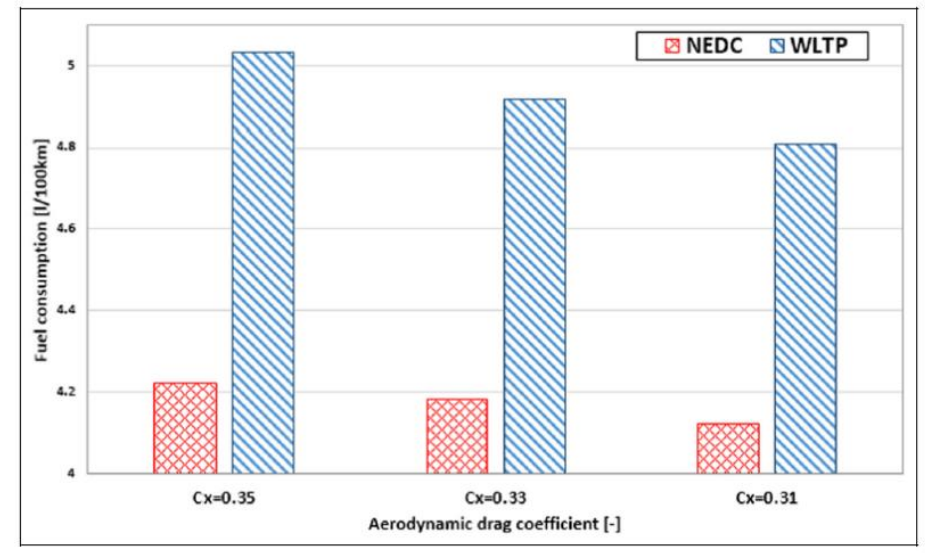

Figure 14 Fuel consumption reduction as a function of the aerodynamic drag coefficinet for a segment $B$ passenger car
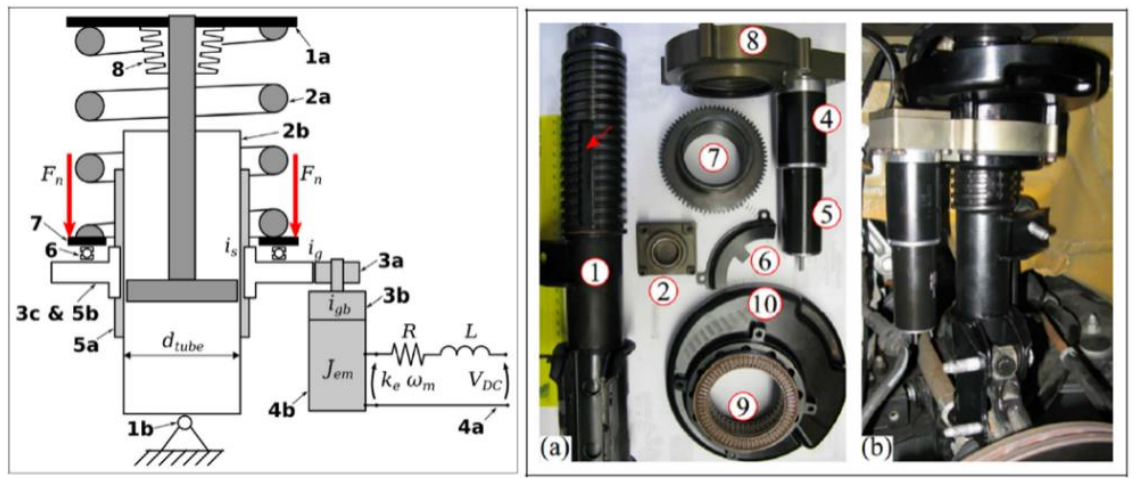

Figure 15 Schematics and an implementation of an irreversible electromechanical system

\section{CONCLUSIONS}

The paper presents a general description of the trend in powertrain hybridization and electrification, highlighting the main features in terms of architectures, functions and advantages as fuel consumption and emission reductions. The proposed analysis focuses also on the current technology status and development trends of two relevant aspects for hybrid and electric vehicles: the battery pack and the energy flow supervisor. A final discussion focuses on the utility of optimizing the global vehicle efficiency. This has been done in the past also in conventional vehicles. The implementation of an electric power unit having as one of the main task the recuperation of the kinetic energy during braking, opens a new scenario. The recuperated kinetic energy that has been stored in a battery systems, needs to be reused in a quick time and in an efficient way. It is not mandatory that the task 
should be accomplished by the electric power unit. The energy can be reused also to power electrified accessories leading to improve other vehicle subsystems (active tensioner, electric ICE accessories, active height adjustment systems). In parallel the presence of at least a $48 \mathrm{~V}$ electric systems motivated the implementation of electrified accessories devoted to recuperate wasted energy (e-turbocompound, regenerative dampers). The vehicle electrification is therefore conceived as vehicle efficiency improvement. Additionally comfort features can also be accomplished.

\section{ACKNOWLEDGMENTS}

This work has been developed in the framework of the research activities at the Center for Automotive Research and Sustainable Mobility (CARS) at Politecnico di Torino (www.cars.polito.it).

\section{REFERENCES}

[1] Ahman, M.: "Assessing the future competitiveness of alternative powertrains", International Journal of Vehicle Design, Vol. 33, 2003, pp. 309-331.

[2] Emadi, A.: “Advanced electric drive vehicles", CRC Press, Taylor \& Francis Group, 2015.

[3] [3]Onori, S., Serrao, L., Rizzoni, G.: "Hybrid electric vehicles - energy management strategies", Springer- Briefs in Control, Automation and Robotics, 2016.

[4] [4]McKay, B.: "48V architectures for enabling high efficiency", Continental Driving Innovation Workshop, Washington DC, 2016. Nearing, Anne G. ASME Style Guide, 2018.

[5] [5]Guzzella, L., Sciarretta, A.: "Vehicle propulsion systems", Springer-Verlag Berlin Heidelberg. 2017.

[6] Bishop, J.D.K., Martin, N.P.D., Boies, A.M.: "Cost-effectiveness of alternative powertrains for reduced energy use and $\mathrm{CO} 2$ emissions in passenger vehicles", Applied Energy, Vol. 124, 2014, pp. 44-61. Doi: 10.1016/j.apenergy.2014.02.019.

[7] Piller, S., Perrin, M., Jossen, A.: "Methods for state-of-charge determination and their applications", Journal of Power Sources, Vol. 96, Iss. 1, 2001, pp. 113-120. Doi: 10.1016/S0378-7753(01)00560-2.

[8] Remmlinger, J., Buchholz, M., Meiler, M., Bernreuter, P., Dietmayer, K.: "State-ofhealth monitoring of lithium-ion batteries in electric vehicles by on-board internal resistance estimation", Journal of Power Sources, Vol. 196, Iss. 12, 2011, pp. 53575363. Doi: 10.1016/j.jpowsour.2010.08.035.

[9] Bonfitto, A., Feraco, S., Tonoli, A., Amati, N., Monti, F.: "Estimation accuracy and computational cost analysis of artificial neural networks for state of charge estimation in lithium batteries", Batteries, Vol. 5, 2019, 47. Doi: 10.3390/batteries5020047.

[10] Bonfitto, A.: "A method for the combined estimation of battery state of charge and state of health based on artificial neural networks", Energies, Vol. 13, Iss. 10, 2548. Doi: $\underline{10.3390 / \text { en13102548. }}$.

[11] Giuseppe, A.P., Belingardi, G.: "Comparing battery electric vehicle powertrains through rapid component sizing", International Journal of Electric and Hybrid Vehicles, Vol. 11, Iss. 1, 2019, pp. 36-58. Doi: 10.1504/IJEHV.2019.098718.

[12] Anselma, P. G., Huo, Y., Roeleveld, J., Belingardi, G., Emadi, A.: "Integration of online control in optimal design of multimode power-split hybrid electric vehicle 
powertrains", IEEE Transactions on Vehicular Technology, Vol. 68, Iss. 4, 2019, pp. 3436-3445. Doi: 10.1109/TVT.2019.2901901.

[13] Liu, W.: "Introduction to hybrid vehicle system modeling and control", John Wiley \& Sons, 2013.

[14] Biswas, A., Emadi, A.: "Energy Management systems for electrified powertrains: state-of-the-art review and future trends", in IEEE Transactions on Vehicular Technology, Vol. 68, No. 7, 2019, pp. 6453-6467.

[15] Trujillo, E.C., Jiménez-Espadafor, F.J., Becerra Villanueva, J.A. García, M.T.: "Methodology for the estimation of cylinder inner surface temperature in an air-cooled engine", Applied Thermal Engineering, Vol. 31, 2011, pp. 1474 -1481. Doi: 10.1016/j.applthermaleng.2011.01.025.

[16] Roberts, A., Brooks, R., Shipway, P.: "Internal combustion engine cold-start efficiency: a review of the problem", causes and potential solutions, Energy Convers Manage, Vol. 82, 2014, pp. 327-350. Doi: 10.1016/j.enconman.2014.03.002.

[17] Di Battista, D., Cipollone, R.: "Improving engine oil warm up through waste heat recovery", Energies, Vol. 11, Iss. 1, 2018, 10. Doi: 10.3390/en11010010.

[18] Kunze, K., Wolff, S., Lade, O., Tonhauser, J.: “A systematic analysis of CO2reduction by an optimized heat supply during vehicle warm-up", SAE Technical Paper 2006-01-1450, 2006. Doi: 10.4271/2006-01-1450.

[19] Tessari, F., Galluzzi, R., Amati, N.: "Efficiency-driven design methodology of gerotor hydraulic units", Journal of Mechanical Design, Vol. 142, No. 6, 2020, 063501. Doi: 10.1115/1.4045421.

[20] Galluzzi, R., Xu, Y., Amati, N., Tonoli, A.: "Optimized design and characterization of motor-pump unit for energy-regenerative shock absorbers", Applied Energy, Vol. 210, 2018, pp. 16-27. Doi: 10.1016/j.apenergy.2017.10.100.

[21] Galluzzi, R., Tonoli, A., Amati, N., Curcuruto, G., Conti, P., Greco, G., Nepote A.: "Regenerative shock absorbers and the role of the motion rectifier," SAE Technical Paper 2016-01-1552, 2016. Doi: 10.4271/2016-01-1552.

[22] Galluzzi, R., Amati, N. Tonoli, A.: "Modeling and characterization of rotary electrohydrostatic actuators", Journal of Vibration and Acoustics, Vol. 138, No. 1, 2015, p. 011016. Doi: 10.1115/1.4031756.

[23]Galluzzi, R., Tonoli, A., Amati, N.: "Modeling, control, and validation of electrohydrostatic shock absorbers", Journal of Vibration and Acoustics, Vol. 137, No. 1, 2015, p. 011012. Doi: 10.1115/1.4028310. 
Intentionally blanc 